\title{
ANALISIS KESALAHAN PESERTA DIDIK SMP DALAM MENYELESAIKAN SOAL KEMAMPUAN BERPIKIR KRITIS BERDASARKAN NEWMAN
}

\author{
Alfian Mubarok ${ }^{* 1}$, Erning Yustiana Dewi ${ }^{2}$ \\ ${ }^{1}$ SMPN 2 Kopo, ${ }^{2}$ SMPN 2 Jawilan \\ masfian2911@gmail.com ${ }^{* 1}$, erningdewi00@gmail.com ${ }^{2}$
}

\begin{abstract}
The purpose of this study is to describe the types and factors of student error in terms of Newman's theory, using questions of mathematical critical thinking skills on the topic of flat-sided shapes. The approach used in this research is qualitative with descriptive methods. The research subjects were selected from State Junior High Schools 2 Kopo in Serang Regency in class VIII, with a total of 20 people who were determined by the results of the analysis of the essay test on critical thinking skills and selected five people to be interviewed. Data collection used critical thinking essay questions test, interview, and documentation. Data from the test results and questions and answers will be analyzed based on data analysis techniques: data reduction, data presentation, and conclusion drawing. The results of this study indicate: 1) stagespercentage of reading the questions is $46 \%$, dua) the error in understanding the questions is 62\%,3) the transformation stage of the questions is 57\%, 4) the process skills stage is $67 \%$, and 5) the writing stage of the final answer is the percentage of $77 \%$. The causative factor is that students are not careful in reading the questions, do not understand the material, do not master the material and others.

Keywords: error analysis; flat side space build; newman theory.
\end{abstract}

\begin{abstract}
Abstrak
Tujuan penelitian ini untuk menggambarkan jenis dan faktor kesalahan anak didik dilihat menurut teori Newman menggunakan soal kritis matematis dalam topik bangun ruang sisi datar. Pendekatan yang digunakan penelitian ini kualitatif menggunakan metode deskriptif. Subjek penelitian yang dipilih bertempat di SMP Negeri 2 Kopo yg ada di Kabupaten Serang pada kelas VIII, menggunakan jumlah 20 orang ditetapkan menggunakan output analisis tes soal esai akal budi kritis dan dipilih 5 orang untuk di wawancarai. Pengumpulan data menggunakan tes soal esai kemampuan berpikir kritis, wawancara, dan dokumetasi. Data output tes \& tanya jawab akan dianalisis dari teknik analisis data yaitu: reduksi data, penyajian data dan penarikan kesimpulan. Hasil penelitian ini menunjukkan: (1) dalam termin kesalahan membaca soal sebanyak 46\%, (2) kesalahan memahami soal sebesar 62\%, (3) kesalahan transformasi soal sebesar 57\%, (4) kesalahan keterampilan proses sebesar 67\%, \& (5) kesalahan menulis jawaban akhir sebanyak $77 \%$. Faktor penyebab adalah peserta didik tidak teliti dalam membaca soal, tidak tahu materi, tidak menguasai materi \& lainnya.

Kata kunci: analisis kesalahan; bangun ruang sisi datar; teori newman.
\end{abstract}

Received: March 27, 2021 / Accepted: April 27, 2021 / Published Online: April 30, 2021 


\section{PENDAHULUAN}

Pendidikan adalah suatu proses yang terus menerus berulang hingga sampai dalam bentuk yang diharapkan. Peran pendidikan sangat krusial buat membentuk warga yang cerdas, berakhlak mulia, demokratis serta bersaing pada era globalisasi. Pendidikan memiliki suatu proses pembelajaran, salah satunya pembelajaran disekolah adalah pembelajaran matematika.

Matematika merupakan cabang ilmu didalam pendidikan, karena selalu diajarkan disetiap strata pendidikan, mulai dari kanak-kanak hingga perguruan tinggi (Early, 2017). Untuk memahami matematika diperlukan proses berpikir. Menurut (Fisher, 2011) salah satu proses berpikir merupakan berpikir kritis yaitu berpikir apa yg diyakini dan dikerjakan. Menurut (Kholifah, 2017) kemampuan berpikir kritis merupakan bagian dari penalaran, dimana penalaran mencangkup pemikiran awal, daya pikir secara kritis (critical thingking), sehingga kemampuan berpikir kritis menjadi bagian penting dalam mengusut matematika.

Pembelajaran matematika hendaknya tidak hanya diarahkan lebih ke penguasaan rumus dan pemahaman konsep, namun pada kecakapan berpikir juga, khususnya dalam kecakapan berpikir kritis. Pentingnya mempunyai kemampuan berpikir kritis juga tercantum pada salinan lampiran Permendikbud Nomor 58 tahun 2014 tentang Kurikulum 2013 jenjang Sekolah Menengah Pertama/MTs (Early, 2017). Faktor yang mendasari Kurikulum 2013 dikembangkan yakni untuk penyempurnaan pola pikir, salah satunya pada pola pembelajaran kritis (Early, 2017). Sehingga pembelajaran berpusat pada peserta didik \& peserta didik wajib aktif di saat proses pembelajaran. Pada kurikulum 2013 dijelaskan juga bahwa pembelajaran yang awalnya tidak aktif menjadi pembelajaran yang kritis atau mencari tahu, untuk menyeimbangkan soft skill \& hard skill (Himmi, 2016).

Kritis dalam artian bukan kemampuan memakai rumus atau perhitungan saja yang anak didik dapatkan pada mengerjakan soal matematika, tetapi harus melibatkan daya berpikir kritis anak didik ketika memecahkan soal matematika kontekstual (Mahmudah, 2018). Sehingga dengan begitu kemampuan berfikir kritis peserta didik bisa berkembang dengan terus dilatih dan diasah, karena dalam setiap pembelajaran, berpikir kritis peserta didik dilibatkan dengan baik. Kemampuan berpikir kritis di zaman sekarang ini sangat krusial, sehingga kemampuan berfikir kritis selalu terus berupaya diasah dan dikembangkan. 
Penerapan berfikir ktitis matematis pada pembelajaran belum optimal, pada umumnya berpikir kritis masih rendah. Beberapa peneliti menerangkan bahwa hasil penelitian yang dilakukan (Fatmawati, Mardiyana, \& Triyanto, 2014) menyatakan bahwa anak didik memiliki kemapuan berpikir kritis yang rendah. Penelitian (Pertiwi, 2018) juga menyatakan berpikir kritis matematis peserta didik berada pada kategori rendah, untuk setiap indikator berfikir kritis ratarata masih dibawah 50\%, terutama pada indikator mengevaluasi \& menginferensi. Sejalan dengan hasil observasi (Andini \& Warmi, 2019) menyatakan bahwa peserta didik yang menjawab lebih berdasarkan Kriteria Ketuntasan Minimal (KKM) sebanyak 0\%, peserta didik yg menjawab hampir mendekati/sinkron dengan KKM sebesar 8\% dan sisanya sebesar 92\% menjawab dibawah KKM. Rata-rata presentase total indikator sebesar $41,54 \%$, yg artinya kemampuan berfikir kritis peserta didik berada dalam kategori rendah.

Rendahnya kemampuan berfikir kritis peserta didik diduga disebabkan peserta didik belum cukup terlatih menyelesaikan soal kontekstual yang menuntut peserta didik untuk menggunakan logikanya dan penalarannya. Banyak peserta didik kesulitan menyelesaikan soal berpikir kritis. Kesulitan inilah yang mengakibatkan rendahnya kemampuan berpikir kritis peserta didik sehingga perlu dilakukan suatu analisis kesalahan hasil jawaban peserta didik untuk mengetahui jenis kesalahan yang peserta didik lakukan. Hasil analisis kesalahan jawaban peserta didik diharapkan dapat dijadikan sebagai bahan acuan pendidik dalam memberikan bantuan kepada anak didik dengan tepat, sehingga dimasa mendatang kemampuan berfikir kritis peserta didik semakin baik.

Analisis kesalahan dalam penelitian ini menggunakan mekanisme Newman. Menurut (Mahmudah, 2018) kesalahan dibedakan menjadi empat tipe didalam menuntaskan soal matematika, yaitu (1) kesalahan membaca, dimana anak didik keliru membaca keterangan utama, akibatnya menghasilkan jawaban yang salah; (2) kesalahan memahami,dimana tidak memahami materi terutama pada penerapan rumus,peserta didik tidak menyadari masalah apa yang diberikan \& kurang tepat dalam mendapati informasi; (3) kesalahan transformasi, dimana tidak sanggup melakukan operasi hitung dan merubah ke dalam matematika; (4) kesalahan keterampilan proses, dimana peserta didik salah pada mengerjakan perhitungan.

Menyelesaikan soal cerita matematika peserta didik banyak ditemukan kesalahan pada proses penyelesaiannya. Menurut (Fatahillah, Wati, \& Susanto, 2017 ; Sholihah, 2018) sebagian 
dari beberapa peserta didik masih merasakan keliru dalam menyelesaikan soal matematika, peserta didik acapkali kesulitan dalam menuliskan satuan, tidak menulis kesimpulan dalam lembar jawaban atau menuliskan kesimpulan namun kurang tepat. Sama halnya dalam penelitian (Darmawan et al., (2018) di sekolah Sekolah Menengah pertama Negeri 16 Bandung tahun ajaran 2017/2018 diperoleh output menurut pengerjaan peserta didik pada soal berpikir kritis matematik. Pada kesalahan membaca soal dalam nomor satu sebesar 22 anak didik. Kesalahan memahami sebanyak 14 peserta didik pada soal dua \& soal tiga. Kesalahan transformasi sebesar 5 orang di angka 4. Untuk kesalahan menuliskan kesimpulan dalam akhir jawaban yang melakukan kesalahan sekitar 8 yaitu soal nomor lima. Rekaptulasi presentase dan faktor kesalahan : (1) kesalahan membaca soal sebesar 13\%, faktor penyebabnya peserta didik tidak memahami pertanyaan yg diajukan \& kurang ketelitian, (2) kesalahan memahami 3.7\%, faktor penyebab peserta didik belum mampu menangkap masalah informasi, (3) kesalahan transformasi $12.2 \%$, faktor penyebabnya tidak mampu menyusun makna kata yg ubah berdasarkan bahasa ekspresi ke dalam bahasa matematika, (4) kesalahan keterampilan proses 9.7\%, karena kesalahan yang dilakukan sebelumnya, kurang teliti, (lima) Kesalahan jawaban akhir 16.7\%, belum terlatih pada mengerjakan suatu perkara dalam bentuk narasi.

Berdasarkan uraiaian latar belakang, maka peneliti akan melakukan analisis jenis kesalahan dan faktor anak didik melakukan kesalahan dalam menyelesaikan soal berpikir kritis menurut Newman dalam topik bangun ruang sisi datar. Jika ditinjau dari beberapa hasil riset sebelumya, maka penelitian ini baru pertama kali dilakukan di SMPN 2 Kopo. Tujuan penelitian ini untuk mendeskripsikan jenis dan faktor kesalahan peserta didik ditinjau berdasarkan teori Newman, menggunakan soal berfikir kritis matematis pada topik bangun ruang sisi datar dalam peserta didik kelas VIII SMPN 2 Kopo.

\section{METODE PENELITIAN}

Penelitian ini memakai pendekatan kualitatif deskriptif. Penelitian dilakukan di SMPN 2 Kopo. Subjek penelitian adalah peserta didik kelas VIII-C tahun ajaran 2019/2020 sebesar 20 anak didik dengan peserta didik yg diwawancara sebanyak lima orang.

Instrumen yang digunakan telah dilakukan uji validasi, reliabilitas, daya pembeda dan indeks kesukaran. Teknik Pengumpulan data menggunakan tes soal esai kemampuan berfikir secara kritis sebanyak lima soal, tanya jawab, dokumentasi. 
Pada tahap analisis data dilakukan dengan 3 tahap yaitu reduksi data, penyajian data dan penarikan kesimpulan. Tahap reduksi data dilakukan dengan memakai tes soal berfikir kritis berbentuk soal esai menggunakan pemberian skor menurut hasil yang dicapai. Pada tahap penyajian data dilakukan dengan penyajian data hasil tes uraian kemampuan berpikir kritis yg kemudian dapat dipilih untuk dilakukan proses selanjutnya yakni tanya jawab. Selanjutnya penarikan kesimpulan untuk dianalisis kesalahan newman dari output tes uraian tentang bangun ruang sisi datar dari indikator kemampuan berfikir kritis matematis.

\section{HASIL DAN PEMBAHASAN}

Penelitian ini dilakukan dengan cara online/daring melalui Platform Whatsapp. Mengingat situasi ketika ini pembelajaran dilakukan pada tempat tinggal karena pandemi Covid-19 sehingga pelaksanaan penelitian ini yg seharusnya dilakukan secara langsung diganti menjadi penelitian online/daring.

Pelaksanaan penelitian ini dilakukan dengan memberikan soal kemampuan berpikir kritis kepada peserta didik melalui Whatsapp dan anak didik balik mengirimkan jawabannya melalui Whatsapp dalam saat itu juga.

Berdasarkan analisis jawaban peserta didik diperoleh data output tes berikut ini.

\begin{tabular}{|c|c|c|c|c|c|}
\hline & \multicolumn{2}{|c}{ Jenis Kesalahan } \\
\hline & Kesalahan & Kesalahan & Kesalahan & Kesalahan & Kesalahan \\
Membaca & Memahami & Transformasi & Ketrampilan & Jawaban \\
\hline 1 & 11 & 14 & 10 & 12 & Akhir \\
\hline 2 & 6 & 8 & 7 & 7 & 15 \\
\hline 3 & 8 & 10 & 12 & 14 & 14 \\
\hline 4 & 9 & 12 & 11 & 15 & 13 \\
\hline 5 & 11 & 17 & 16 & 18 & 19 \\
\hline Jumlah & $\mathbf{4 5}$ & $\mathbf{6 1}$ & $\mathbf{5 6}$ & $\mathbf{6 6}$ & $\mathbf{7 6}$ \\
\hline
\end{tabular}

Tabel 1. Kesalahan Peserta didik Ditinjau Teori Newman

Berdasarkan Tabel 1 diperoleh berita bahwa berdasarkan jenis kesalahan dalam tahap membaca soal 18 anak didik melakukan kesalahan, jumlah kesalahan secara holistik sebesar 45. Kesalahan memahami soal 19 peserta didik, jumlah secara keseluruhan sebanyak 61. Kesalahan 
transformasi soal 19 peserta didik melakukan kesalahan, jumlah kesalahan secara keseluruhan sebesar 56. Kesalahan keterampilan proses soal 18 anak didik, jumlah kesalahan secara keseluruhan sebesar 66. Kesalahan menuliskan jawaban akhir 19 anak didik, jumlah kesalahan keseluruhan sebanyak 76. Berikut tabel rekaptulasi presentase kesalahan peserta didik berdasarkan kesalahan Newman.

\begin{tabular}{|c|c|c|}
\hline No & Jenis Kesalahan & Persentase \\
\hline 1 & Kesalahan Membaca & $45 \%$ \\
\hline 2 & Kesalahan Memahami & $61 \%$ \\
\hline 3 & Kesalahan Transformasi & $56 \%$ \\
\hline 4 & Kesalahan Ketrampilan Proses & $66 \%$ \\
\hline 5 & Kesalahan Jawaban Akhir & $76 \%$ \\
\hline
\end{tabular}

Tabel 2. Rekaptulasi Presentasi Kesalahan Berdasarkan Teori Newman

Berdasarkan data dalam Tabel dua diperoleh bahwa kesalahan membaca soal presentasenya sebesar 45\%, kesalahan tahu 61\%, kesalahan transformasi 56\%, kesalahan keterampilan proses 66\%, dan kesalahan jawaban akhir 76\%. Presentase terbesar berada pada kesalahan jawaban akhir. Hal ini dikarenakan dalam jawaban akhir (kesimpulan) banyak anak didik yang tidak menuliskannya, ada juga terjadi karena kesalahan sebelumnya sehingga berpengaruh ke jawaban akhir.

Berikut diuraikan kesalahan anak didik menurut teori Newman dan faktor kesalahan pada menjawab soal uraian yg diperoleh menurut wawancara pada lima orang peserta didik.

\section{A. Kesalahan Membaca Soal}

Kesalahan membaca menurut (Prakitipong \& Nakamura, 2006; Humaerah, 2017) yaitu kesalahan anak didik waktu membaca soal anak didik dalam mencari informasi kurang baik, membaca simbol pada soal. Berikut jawaban galat satu peserta didik pada soal angka 1. 


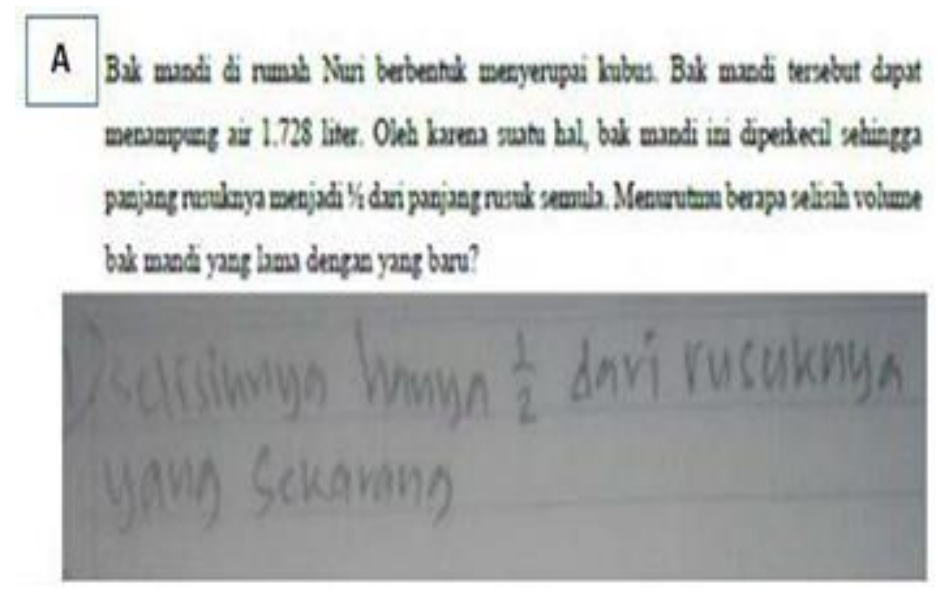

Gambar 1. Jawaban Peserta didik Subyek S1

Berdasarkan Gambar 1, kesalahan yg dilakukan peserta didik yaitu tidak mengetahui kata kunci soal, anak didik hanya menjawab langsung pada konklusi tidak ada proses yang peserta didik kerjakan dilembar jawabannya. Beberapa istilah kunci / fakta tidak dituliskan pada lembar jawabannya. Sehingga jawaban yang peserta didik tuliskan slah tidak sama dengan apa yg dimaksud soal.

Tanya jawab yg dilakukan peneliti pada subyek S1 :

Peneliti : "coba anda baca soalnya \& kabar apa yg anda dapatkan?"

S1 : "volume bak mandi $1.728 \mathrm{~cm} 3$. dan ditanyakan selisih bak mandinya"

Peneliti : "coba tunjukan rumus yangharus dipakai"

S1 : "ngga tau ka, saya hanya nalar saja lantaran kan diperkecil $1 \frac{1}{2}$ dari sebelumnya jadi saya akal aja bak baru nya ya $1 / 2$ menurut yg lama”.

Berdasarkan wawancara subyek S1 diperoleh faktor penyebab kesalahan peserta didik pada membaca soal yaitu: (1) anak didik saat membaca soal kurang teliti, sehingga melewati fakta yg terdapat dalam soal, ketidaktahuan anak didik pula dalam materi. Penelitian oleh (Satoto, Sutarto, \& Pujiastuti, 2012) menemukan peserta didik mengalami kesalahan membaca soal karena kurang mampu membaca kata kunci, simbol yang terdapat pada soal. Begitu jua penelitian oleh (Suci, 2016) juga menyampaikan bahwa anak didik bisa membaca dengan lancar, tetapi saat memahami kalimat, peserta didik tidak memaknai dengan baik, sehingga hal ini bisa menyebabkan kesalahan pada membaca soal. 


\section{B. Kesalahan Memahami Soal}

Menurut (Prakitipong \& Nakamura, 2006; Humaerah, 2017) kesalahan memahami soal yaitu dimana setelah peserta didik membaca soal, tetapi peserta didik tidak bisa tahu permasalahan yg akan diselesaikan, tidak mampu menuliskan diketahui dan ditanyakan dalam lembar jawaban. Berikut pengerjaan peserta didik soal angka dua.

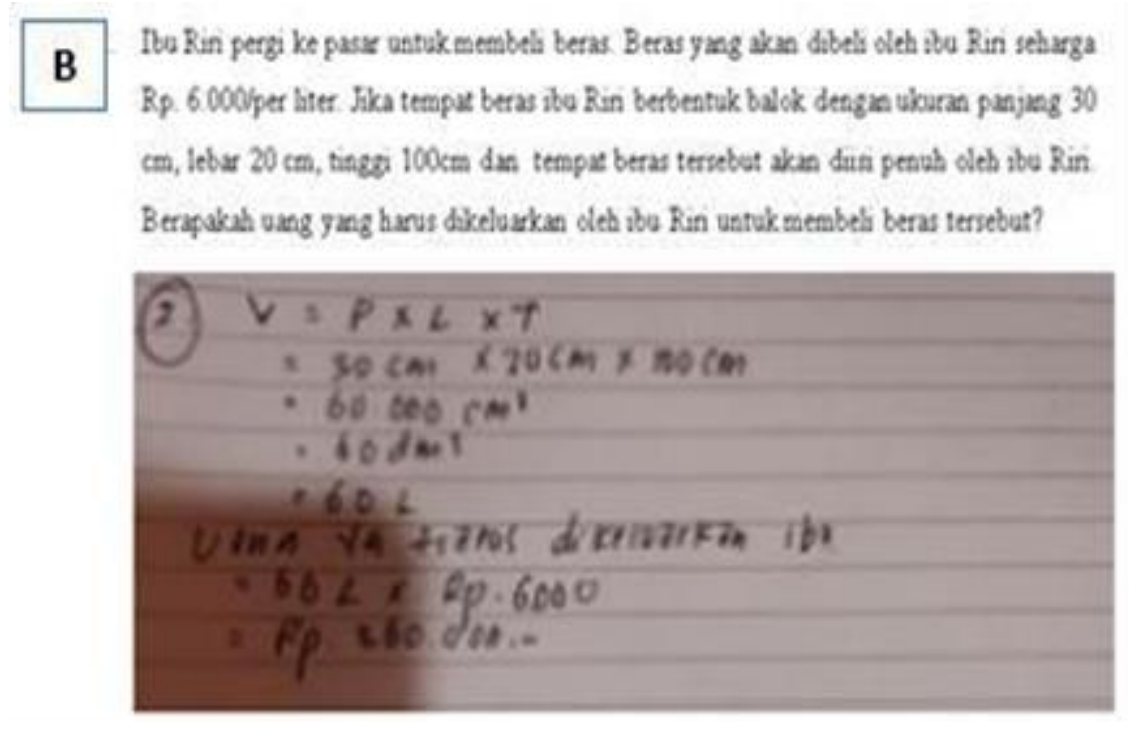

Gambar 2. Jawaban Peserta didik Subyek S2

Terlihat jawaban anak didik pada Gambar 2 bahwa anak didik tidak menuliskan diketahui dan ditanyakan pada lembar jawabannya.

Penelitian oleh (Pradini, 2019) mengemukakan bahwa masih banyak peserta didik yang tidak memiliki kemampuan pada memahami soal yang ditunjukkan dengan tidak menuliskan diketahui dan ditanyakan pada lembar jawaban, dan terdapat beberapa peserta didik yang dapat menuliskan namun tidak benar dan tidak sinkron.

Berikut hasil tanya jawab peneliti dengan subyek S2 :

Peneliti : "kenapa pada lbr jawaban anda tidak menuliskan apa yang diketahui dan ditanyakan"

S2 : : "iya pak saya lupa pak, \& saya kurang biasa menuliskan hal seperti itu dalam mengisi soal"

Peneliti : "coba sebutkan rumus yg di pakai pada soal tersebut"

S2 : "rumusnya $V=\mathrm{p} \times 1 \times \mathrm{t}$, tinggal dikalikan saja pak yang sudah diketahui pada soal sehingga mendapatkan hasil $=60.000 \mathrm{~cm}^{3} . "$ 
Peneliti : "itu bisa jadi 601 di dapat dari mana?"

Berdasarkan wawancara di atas diperoleh faktor penyebab kesalahan peserta didik dalam memahami soal yaitu tidak biasa dalam lembar jawaban menuliskan diketahui dan ditanyakan. Hal ini serupa dengan penelitian (Humaerah, 2017) dimana mengungkapkan ketidak telitian peserta didik, ketidak tahuan anak didik, kecerobohan dalam memilih hal penting pada soal, ketidak biasaan dan ketidak telitian anak didik pada saat membaca soal sehingga menjadi penyebab kesalahan anak didik dalam memahami sebuah soal.

\section{Kesalahan Transformasi}

Menurut (Prakitipong \& Nakamura, 2006; Humaerah, 2017) kesalahan transforamsi yaitu kesalahan yang terjadi dimana peserta didik dapat memahami masalah dalam soal, tetapi tidak bisa menentukan rumus atau operasi matematika untuk menyelesaikannya. Berikut jawaban S3 pada soal angka tiga.

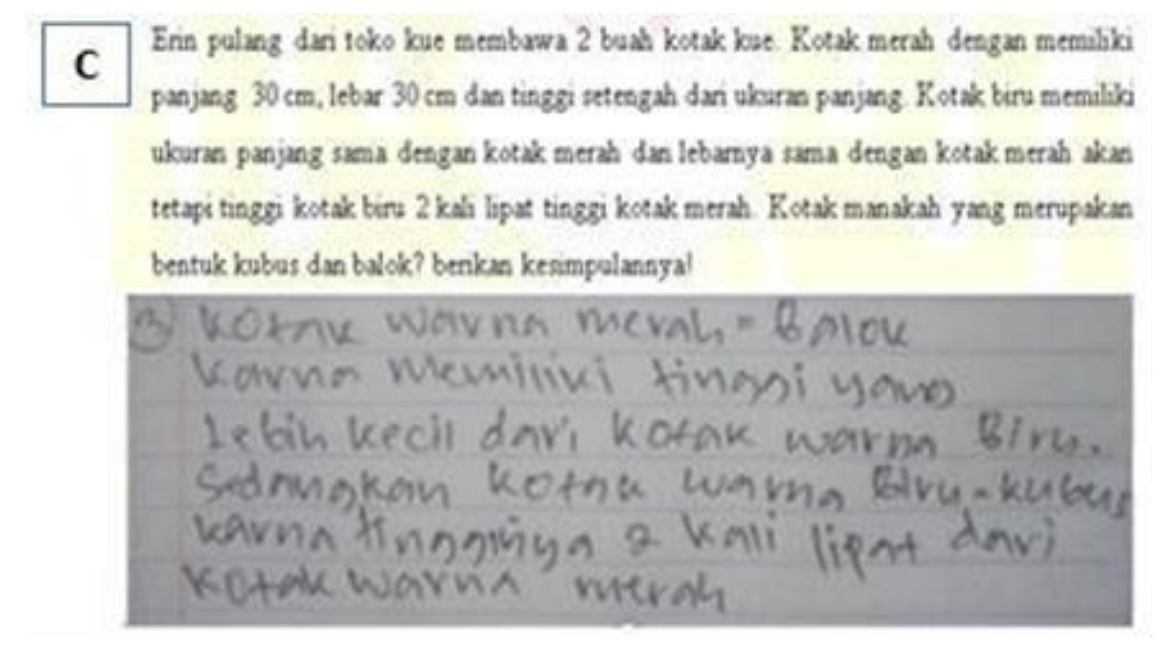

Gambar 3. Jawaban Peserta didik Subyek S3

Terlihat dalam Gambar 3, bahwa peserta didik tidak melakukan operasi perhitungan apapun pada lembar jawabannya. Peserta didik hanya memberikan sebuah konklusi / kesimpulan dalam lembar jawabannya. Berikut tanya jawab yang dilakukan dalam subjek S3 :

Peneliti : : "coba tunjukkan proses pengerjaan anda, hingga bisa menyimpulkan seperti pada lembar jawaban".

S3 : "dipandang berdasarkan berukuran sisi-sisinya pak, kan kotak merah tingginya lebih kecil daripada kotak biru". 
Peneliti : : :hanya menebak saja? Tidak coba menggambarkannya?

$$
\text { :“ tidak pak”. }
$$

Berdasarkan tanya jawab pada subyek S3 dapat diperoleh faktor peserta didik mengalami kesalahan transformasi yaitu peserta didik tidak paham materi yang terdapat dalam soal, tidak mampu menentukan metode penyelesaian, akibatnya menjawab dengan menebak saja. Sama halnya dengan penelitian yang dilakukan (Humaerah, 2017) bahwa ketidak pahamaan peserta didik menggunakan metode penyelesaian yang akan dipakai, anak didik tidak fokus, tidak memilih rumus dan tidak paham dengan materinya, kurang menyukai matematika, ssehingga dapat mejadi faktor peserta didik mengalami kesalahan pada mentransformasikan soal.

\section{Kesalahan Keterampilan Proses}

Menurut Prakitipong dan Nakamura dalam (Prakitipong \& Nakamura, 2006; Humaerah, 2017) bahwa keterampilan proses adalah kesalahan yang peserta didik lakukan didalam proses pengoperasian perhitungan atau dengan istilah lain dalam menentukan rumus yg tepat tetapi tidak bisa menghitung atau tidak dapat menjalankan prosedur operasi matematika dengan baik. Kesalahan transformasi bisa juga terjadi lantaran kesalahan sebelumnya, berdasarkan kesalahan membaca soal, kesalahan memahami. Berikut gambar jawaban anak didik dalam menjawab soal nomor 4 .

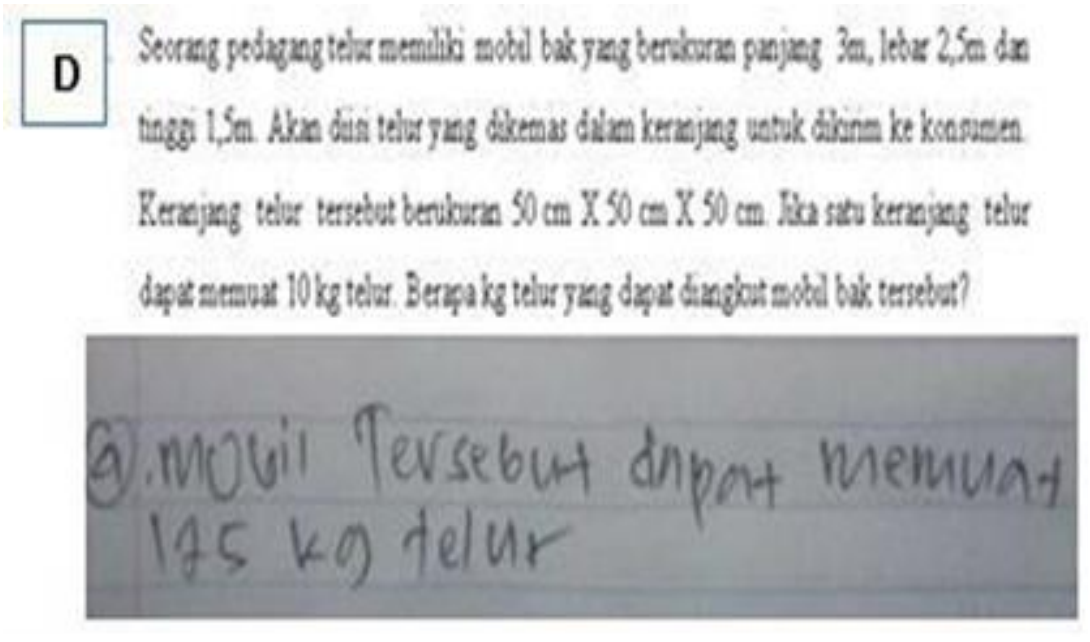

Gambar 4. Jawaban Peserta didik Subyek S4

Terlihat dalam menjawab soal, peserta didik subyek S4 belum optimal menjalankan prosedur perhitungan. Kesalahan ini terjadi karena anak didik mengalami kesalahan sebelumnya, anak didik tidak mampu menentukan mekanisme penyelesaian. Sejalan dengan penelitian 
(Humaerah, 2017) menyatakan kesalahan yang peserta didik lakukan tidak lepas dari kesalahan sebelumnya. Berikut tanya jawab subyek S4 dalam soal angka 4:

Peneliti : : "coba jelaskan dan tunjukkan rumus yang wajib digunakan buat menjawab

S4 soal tersebut?"

Peneliti : "jawaban anda di dapat dari mana?"

S4 : "teman pak (sembari tersenyum)"

Berdasarkan wawancara subyek S4 diperoleh faktor penyebab kesalahan peserta didik dalam keterampilan proses yaitu: (1) akibat kesalahan peserta didik sebelumnya tidak memahami materi; (dua) peserta didik tidak paham memilih rumus penyelesaian. Sementara menurut (White, 2010) bahwa peserta didik yg baik dalam memiliki keterampilan proses adalah mereka yang dapat memahami tahapan dan langkah operasi perhitungan matematika pada penyelesaian soal dengan benar.

\section{E. Kesalahan Menuliskan Jawaban Akhir}

Menurut (Prakitipong \& Nakamura, 2006; Humaerah, 2017) bahwa menuliskan jawaban akhir adalah kesalahan yang peserta didik lakukan karena ketidak telitian anak didik pada menulis yang mengakibatkan berubahnya makna jawaban. Peserta didik sudah mampu melakukan penyelesaian soal dengan benar, namun keliru dalam menuliskan apa yang dimaksudkan. Berikut gambar hasil pengerjaan peserta didik nomor lima.

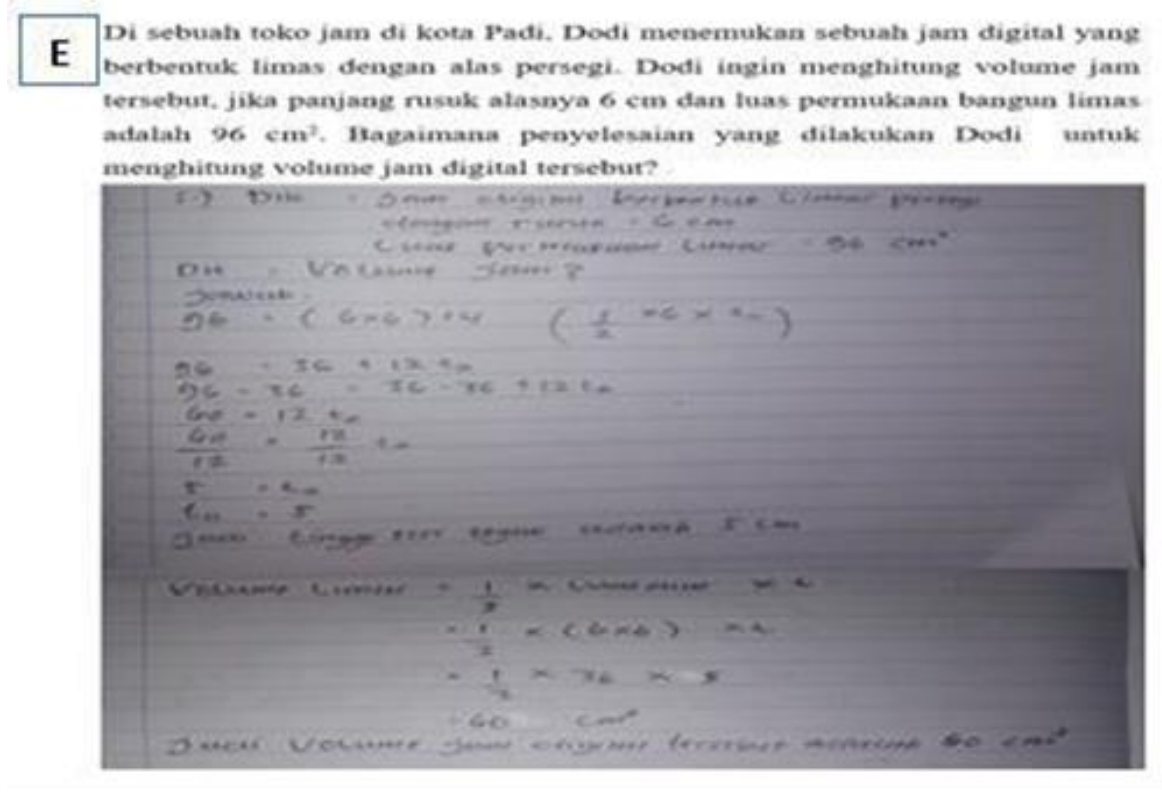


Gambar 5. Jawaban Peserta didik Subyek S5

Peserta didik mampu menarik kesimpulan pada jawabannya, namun kurang tepat. Kesalahan jawaban ini terjadi karena kesalahan sebelumnya dimana anak didik bisa menentukan rumus penyelesaian namun pada keterampilan prosesnya anak didik mengalami kesulitan atau kekeliruan dalam pengoperasian, sehingga mengakibatkan jawaban akhir peserta didik keliru.

Berikut tanya jawab peserta didik jawaban soal nomor lima oleh subyek S5:

Peneliti : : "Tolong jelaskan bagaimana anda mengerjakan soal tadi"

S5 : "Rusuk limas $6 \mathrm{~cm}$. Luas 96 ditanyakan volume limas. Kan volume limas itu $1 / 3 \mathrm{x}$ luas alas x tinggi limas. Nah karena tingginya belum diketahui jadi mencari tinggi limas berdasarkan yg diketahui pada soal pak, didapat tingginya 5 , jadi volume jam tersebut jawabannya $60 \mathrm{~cm} 3$.

Peneliti : : Apakah kamu yakin?”

S5 : (diam dan tersenyum saja)

Berdasarkan wawancara di atas diperoleh faktor penyebab kesalahan anak didik dalam menuliskan jawaban akhir yaitu: (1) peserta didik keliru dan bingung, (2) belum memahami materi tentunya, dan (3) kesalahan sebelumnya. Kesalahan inilah yg banyak dilakukan peserta didik, mungkin karena faktor kesalahan sebelumnya. Penelitian (Hariyani \& Aldita, 2020) menemukan bahwa anak didik banyak melakukan kesalahan dalam jawaban akhir karena ketidak mampuannya pada menuliskan jawaban akhir dengan benar dan lengkap.

\section{KESIMPULAN DAN SARAN}

Berdasarkan hasil analisis data bisa disimpulkan jenis kesalahan ditinjau dari teori Newman dan faktor penyebab kesalahan sebagai berikut: (1) kesalahan membaca soal presentase sebesar $45 \%$. Adapun faktor penyebabnya yaitu peserta didik tidak saksama dalam membaca soal, anak didik tidak bisa menemukan informasi penting pada soal; (2) kesalahan memahami soal presentase sebesar $61 \%$. Faktor penyebabnya kurang memahami materi dengan baik, tidak biasa menulis diketahui dan ditanyakan; (3) kesalahan transformasi soal presentasenya sebanyak 56\%. Faktor penyebabnya peserta didik nir mengerti materi soal menggunakan baik, sehingga sulit dalam menentukan rumus penyelesaian; (4) kesalahan keterampilan proses presentasenya sebesar $66 \%$. Faktor penyebabnya anak didik mengalami kesalahan yaitu peserta didik tidak mampu memilih rumus penyelesaian, sehingga anak didik menjawab dengan asal-asalan, dan dampak 
kesalahan sebelumnya; (5) kesalahan menuliskan jawaban akhir presentasenya sebesar 76\%. Kesalahan ini yang seringkali dilakukan oleh peserta didik. Faktor penyebabnya karena kesalahan sebelumnya, tidak menuliskan jawaban akhir/kesimpulan.

Saran bagi peneliti selanjutnya bisa dijadikan bahan rekomendasi untuk penelitian lebih lanjut tentang kesalahan-kesalahan newman khususnya soal kemampuan berpikir kritis pada jenjang lebih tinggi,dan dapat menambahkan solusi permasalahan yang bisa meminimalisir kesalahan-kesalahan kedepannya.

\section{DAFTAR PUSTAKA}

Andini, V., \& Warmi, A. (2019). Analisis Tingkat Kemampuan Berpikir Kritis Matematis Peserta didik Sekolah Menengah pertama Kelas VIII Pada Materi Relasi dan Fungsi. Prosiding Sesiomadika: Seminar Nasional Matematika Dan Pendidikan Matematika, 2(1), 602-609.

Darmawan, I., Kharismawati, A., Hendriana, H., \& Purwasih, R. (2018). Analisis Kesalahan Peserta didik Sekolah Menengah pertama Berdasarkan Newman pada Menyelesaikan Soal Kemampuan Berpikir Kritis Matematis dalam Materi Bangun Ruang Sisi Datar. JURING (Journal for Research in Mathematics Learning), 1(1), 71-78. https://doi.Org/10.24014/juring.V1i1. 4912

Early, O. A. (2017). Analisis Kemampuan Berpikir Kritis Matematika Ditinjau menurut Kemandirian Peserta didik Kelas VIII melalui Pembelajaran Model PBL Pendekatan Saintifik Berbatuan FUN PICT. (Universitas Negeri Semarang). Retrieved from https://lib.Unnes.Ac.Id/32105/1/41014 13036.Pdf

Fatahillah, A.,Wati, Y. F., \& Susanto. (2017). Analisis Kesalahan Peserta didik dalam Menyelesaikan Soal Cerita Matematika berdasarkan Tahapan Newman bersama Bentuk Scaffolding yang diberikan. Kadikma, 8(1), 40-51. https://doi.Org/10.19184/kdma.V8i1.5229

Fatmawati, H., Mardiyana, \& Triyanto. (2014). Analisis Berpikir Kritis Peserta didik Dalam pemecahan Masalah Matematika Berdasarkan Polya Pada Pokok Bahasan Persamaan Kuadrat. Jurnal Elektronik Pembelajaran Matematika, 2(9), 899-910.

Fisher, A. (2011). Critical Thingking : An Introduction. London: Cambridge University Press. 
Hariyani, S., \& Aldita, V. C. (2020). Analisis Kesalahan Peserta didik pada Menyelesaikan Soal Cerita Sistem Persamaan Linear Dua Variabel Berdasarkan Prosedur Newman. AlKhwarizmi: Jurnal Pendidikan Matematika dan Ilmu Pengetahuan Alam, 8(1), 39-50. Https://doi.Org/10.24256/jpmipa.V8i1.805

Himmi, N. (2016). Perbedaan Self Efficacy Matematis Peserta didik Antara Pembelajaran Berbasis Masalah Berbantuan Geogebra \& Autograph pada MAN 1 Medan. Pythagoras: Jurnal Program Studi Pendidikan Matematika, 5(dua), 165-171.

Humaerah, S. R. (2017). Analisis Kesalahan Peserta didik Dalam Menyelesaikan Soal-Soal Pada Materi Geometri Dengan Prosedur Newman Kelas VIII MTs Muhammadiyah Tanetea Kabupaten Jeneponto. (Universitas Islam Negeri Makassar). Retrieved from http://repositori.Uin-alauddin.Ac.Id/7766/

Kholifah. (2017). Analisis Kemampuan Berfikir Kritis Matematis dalam Peserta didik Sekolah Menengah pertama Kelas IX. (Universitas Islam Negeri Syarif Hidayatullah). Retrieved from http://repository.Uinjkt.Ac.Id/dspace/ bitstream/123456789/36449/1/kholif ah-FITK

Mahmudah, W. (2018). Analisis Kesalahan Peserta didik pada Menyelesaikan Soal Matematika Bertipe HOTS Berdasar Teori Newman. Unisda Journal of Mathematics and Computer Science, 4(1), 49-56.

Pertiwi, W. (2018). Analisis Kemampuan Berpikir Kritis Matematia Peserta Didik SMK Pada Materi Matriks. Jurnal Pendidikan Tambusai, dua(4), 793-801.

Pradini, W. (2019). Analisis Kesalahan Peserta didik Dalam Menyelesaikan Soal Cerita Persamaan Linear Dua Variabel. PYTHAGORAS:Jurnal Pendidikan Matematika, 14(1), 33-45. https://doi.Org/10.21831/pg.V14i1.21481

Prakitipong, N., \& Nakamura, S. (2006).Analysis of Mathematics Performance of Grade Five Students in Thailand Using Newman Procedure. Journal of International Cooperation in Education, 9(1), 111-122.

Satoto, S., Sutarto, H., \& Pujiastuti, E. (2012). Analisis Kesalahan Hasil Belajar Peserta didik Dalam Menyelesaikan Soal Dengan Prosedur Newman. Unnes Journal of Mathematics Education, 1(dua). Https://doi.Org/10.15294/ujme.V1i2.1 757 
Sholihah, M. (2018). Analisis kesalahan peserta didik dalam merampungkan soal cerita matematika kelas VII MTs laboratorium UIN-SU T.P 2017/2018. (Universitas Islam Negeri Sumatera Utara). Retrieved from http://repository.Uinsu.Ac.Id/4014/

Singeran Petronela, Sumadji, \& Yuniar Ika Putri Pranyata. (2020). ANALISIS KESALAHAN SISWA PASIF DALAM MENYELESAIKAN SOAL MATEMATIKA BERBENTUK CERITA. Jurnal Lebesgue: Jurnal Ilmiah Pendidikan Matematika, Matematika Dan Statistika, 1(3), 172-181. doi:10.46306/lb.v1i3.37

Suci, A. D. K. (2016). Analisis Kesalahan Peserta didik dalam Menyelesaikan Soal Cerita Matematika Berdasarkan Tahapan Newman. Ekuivalen, dua(1),19-24.

White, A. L. (2010). Numeracy, Literacy and Newman's Error Analysis. Journal of Science and Mathematics Education in Southeast Asia, 33(2), 129-148. 